\title{
Status Klinis dan Deteksi Lip L32 pada Sapi Seropositif Leptospirosis di Kabupaten Kulon Progo
}

\section{Clinical Status and Detection of Lip L32 in Seropositive Leptospirosis Cattles in Kulon Progo District}

\author{
Guntari Titik Mulyani ${ }^{*}$, Wayan Tunas Artama², Estu Widodo ${ }^{3}$ \\ ${ }^{1 *}$ Departemen Ilmu Penyakit Dalam, Fakultas Kedokteran Hewan,Universitas Gadjah Mada \\ ${ }^{2}$ Departemen Biokimia, Fakultas Kedokteran Hewan, Universitas Gadjah Mada \\ ${ }^{3}$ Bidang Kesehatan Hewan, Dinas Pertanian dan Pangan Kabupaten Kulon Progo, Yogyakarta \\ *Email: guntari@ugm.ac.id
}

Naskah diterima: 7 Mei 2020, direvisi: 8 Januari 2021, disetujui: 8 Februari 2021

\begin{abstract}
Leptospirosis is a zoonotic disease caused by Leptospira interrogans. Animals can act as carriers, spreading Leptospira from urine, and be a source of infection for other animals and humans. In leptospirosis cows can cause abortion, early birth, infertility, decreased milk production and death. The aims of this study was to determine the clinical status and detect the presence of Leptospira with Polymerase Chain Reaction (PCR) from cattles urine i.e leptospirosis seropositive. A total of 12 cattles seropositive leptospirosis by Microscopic Agglutination Test (MAT) were carried out clinical examinations covering general conditions, pulsus, breathing and temperature and organ systems examination. The urine was collected aseptically, then DNA isolation carried out using Genoid. Detection of leptospira in the urine is carried out by detecting the presence of the primary lipoprotein LipL32 composing the Leptospira membrane. The primer employed was as follow forward: 5'-TGG ATC TGA TCA ACT ATT ACG-3 and reverse 5 '-CAC TTC ACC TGG TTT GTA GGT-3'. Amplification was carried out at 40 cycles followed by electrophoresis to determine the band size at $506 \mathrm{bp}$. The results showed that all cows positive for leptospirosis by MAT were clinically healthy PCR showed 7 out of 12 positive samples were sourced from urine. It can be concluded that leptospirosis in cattles do not always show clinical symptoms, but have the potential to excrete leptospires from urine, so they can act as a source of transmission of leptospirosis to humans, and other animals.
\end{abstract}

Keywords: cattles; clinical status; Leptospirosis; LipL32.

\begin{abstract}
Abstrak
Leptospirosis adalah penyakit zoonosis yang disebabkan oleh Leptospira interrogans. Hewan dapat berperan sebagai pembawa, menyebarkan Leptospira bersama urin, dan menjadi sumber infeksi bagi hewan lain dan manusia. Pada sapi leptospirosis dapat menyebabkan aborsi, kelahiran dini, infertilitas, produksi susu turun dan kematian. Penelitian ini bertujuan untuk mengetahui status klinis dan mendeteksi gen LipL32 leptospira dengan Polymerase Chain Reaction (PCR) sampel urin dari sapi seropositif leptospirosis. Sebanyak 12 sapi yang seropositif leptospirosis dengan uji Microscopic Agglutination Test (MAT) dilakukan pemeriksaan klinis meliputi keadaan umum, pemeriksaan pulsus, nafas dan temperatur serta sistema organ. Urin dikoleksi secara aseptis, selanjutnya dilakukan isolasi DNA menggunakan kit dari Genoid. Deteksi leptospira dalam urin dilakukan dengan mendeteksi adanya lipoprotein utama LipL32 penyusun membrane LPS leptospira. Primer yang dipakai adalah forward 5'-TGG ATC TGA TCA ACT ATT ACG-3' dan primer reverse 5'-CAC TTC ACC TGG TTT GTA GGT-3'. Amplifikasi dilakukan sebanyak 40 siklus dan dilanjutkan dengan elektroforesis untuk mengetahui adanya pita yang terbentuk pada ukuran $506 \mathrm{bp}$. Hasil penelitian memberikan gambaran bahwa semua sapi yang positif leptospirosis dengan MAT dalam kondisi sehat secara klinis. Hasil PCR memberikan gambaran 7 dari
\end{abstract}


12 sampel positif ditemukan LipL32 Leptospira interrogans dalam urin yang ditunjukkan dengan terbentuknya pita pada $506 \mathrm{bp}$. Dari hasil penelitian ini dapat disimpulkan bahwa sapi yang positif leptospirosis tidak selalu menunjukkan gejala klinis, namun memiliki potensi mengeluarkan leptospira bersama urin, sehingga dapat berperan sebagai sumber penularan leptospirosis bagi hewan lain, maupun manusia.

Kata kunci: sapi; status klinis; Leptospirosis; LipL32

\section{Pendahuluan}

Leptospirosis adalah penyakit zoonosis yang disebabkan oleh Leptospira interrogans yang masuk genus Leptospira, family Leptospiraceae dan ordo Spirochaetales. Leptospirosis menyerang hampir semua mamalia, termasuk manusia. Hewan dapat bertindak sebagai karier yang dapat menyebarkan Leptospira, terutama bersama urin dan menjadi sumber penularan bagi hewan lain dan manusia (Thaipadungpanit et al., 2011). Leptospira bersifat aerobik, motil, gram negatif, bentuknya dapat berkerut-kerut, dan terpilin dengan ketat. Leptospira memiliki 3 komponen utama, yaitu : protoplasmik spiral, filament axial (230 - $250 \mathrm{~A})$, dan kompleks amplop yang melindungi organisme. Amplop luar Leptospira tersusun atas protein, lemak dan lipopolisakarida (Adler dan Moctezuma, 2010).

Leptospirosis memiliki distribusi geografis yang luas dan terjadi di daerah tropik, sub tropik dan daerah yang hangat. Iklim yang cocok untuk perkembangan Leptospira adalah udara yang hangat, tanah yang lembab/basah dan $\mathrm{pH}$ alkalis. Keadaan demikian banyak dijumpai di negara tropik sepanjang tahun, termasuk di Kulon Progo wilayah yang banyak memiliki sungai. Penularan dapat langsung maupun tidak langsung, peranan hewan dalam penyebaran leptospirosis sangat potensial (Adler and Moctezuma, 2010).

Tanda-tanda klinis yang terkait dengan leptospirosis sapi bervariasi dan tergantung pada serovar yang menginfeksi dan kerentanan hewan. Secara klinis, leptospirosis sapi sulit untuk didiagnosis karena gejalanya tidak spesifik dan mudah disalahartikan dengan penyakit lain (Brown et al., 2011). Infeksi biasanya didapat pada usia dini, dan prevalensi ekskresi kronik melalui urin meningkat dengan bertambahnya umur hewan. Leptospirosis akan menetap sebagai infeksi kronik dalam tubulus ginjal inang reservoir, dan akan dikeluarkan bersama urin dan merupakan sumber penularan leptospirosis (Besung, 2012). Leptospira dapat bertahan hidup selama 74 hari di tanah dan dapat tumbuh dan berkembang pada kondisi yang memungkinkan (Vijayachari, 2007).

Menurut Vijayachari et al., (2007), MAT adalah Gold standart untuk mendiagnosis leptospirosis karena kemampuannya mendeteksi antibodi spesifik terhadap spesies Leptospira dalam sampel serum. Ahmed et al., (2012) telah menyarankan teknik PCR karena memberikan keuntungan substansial dibandingkan isolasi dan teknik MAT, PCR dirasa lebih murni, waktu penyelesaian cepat, dan tidak perlu memelihara leptospira hidup dalam berbagai serovar. Musso et al., (2013) mengatakan bahwa keuntungan dari diagnosis berbasis asam nukleat terletak pada kemampuannya untuk mendapatkan diagnosis pasti selama tahap akut penyakit bahkan sebelum antibodi dapat dideteksi.

Beberapa sasaran yang dapat digunakan dalam PCR Leptospira adalah : (1) RNA, seperti 16SrRNA, 23SrRNA, (2) komponen dalam membran luar Leptospira seperti : LipL21,LipL32, LipL41, OmpL1 dan (3) immunoglobulin-like (Lig) gen, seperti LigA, LigB, LigC serta (4) antigen dalam flagella, seperti fla A dan fla B (Satbige, et el., 2020). Teknik PCR dengan target wilayah gen protein permukaan LipL32 hanya mampu mendeteksi L. interrogans. Metode ini mampu mendeteksi 100 leptospira / mL plasma, serum atau darah utuh, dan 0,7 setara genom (GE) / reaksi jaringan parafin (Gonzales et.al., 2013). Lipoprotein L32 adalah protein yang paling menonjol dalam profil protein Leptospira, lipoprotein ini penting dalam patogenesis, diagnosis, dan pencegahan leptospirosis (Haake et al., 2010).

Penelitian ini bertujuan untuk mengetahui status klinis dan keberadaan Leptospira interrogans dalam urine sapi yang seropositif leptopirosis dengan mendeteksi adanya LipL32. Sapi 
yang mengeluarkan Leptospira interrogans bersama urin tanpa menunjukkan gejala klinis, merupakan sumber penularan yang tidak disadari.

\section{Materi dan Metode}

Penelitian ini diawali dengan melakukan deteksi leptospirosis terhadap sapi di wilayah aliran sungai Progo, kabupaten Kulon Progo, Daerah Istimewa Yogyakarta. Microscopic Agglutination Test (MAT) dilakukan dengan mereaksikan serum sapidengan 14jenis serovarLeptospirainterrogans, yaitu serovar : Ichterohaemorrhagiae, Javanica, Celledoni, Ballum, Pyrogenes, Cynopeteri, Rachmati, Auatralis, Pomona, Canicola, Grippotyphosa, Bataviae, Hardjo, Tarrasovi. Sebanyak 12 sapi yang seropositif leptospirosis dilakukan pemeriksaan klinis meliputi keadaan umum, pemeriksaan pulsus, nafas dan temperatur serta kondisi tubuh. Sapi dinyatakan sehat secara klinis jika memiliki kondisi tubuh sedang dengan BCS minimal 2-3, ekspresi muka tenang, pulsus $60-70$ kali/menit, nafas 24-42 kali/menit dan suhu 37,5$39,5^{\circ} \mathrm{C}$.

Polymerase Chain Reaction dilakukan terhadap 12 sampel urin sapi seropositif yang dikoleksi secara aseptis, selanjutnya disentrifus dan endapannya dilakukan isolasi DNA menggunakan kit dari Genoid. Deteksi leptospira dalam urin dilakukan dengan mendeteksi adanya lipoprotein utama LipL32 penyusun membrane LPS Leptospira. Primer didesain dengan primer forward sepanjang 21 basa: 5'-TGG ATC TGA TCA ACT ATT ACG-3' yang mengandung GC $38,1 \%$ dengan $\mathrm{Tm} 57,2^{\circ} \mathrm{C}$. Primer reverse sepanjang 22 basa diperoleh: 5'-CAC TTC ACC TGG TTT GTA GGT-3' yang mengandung GC $45,5 \%$ dengan $\mathrm{Tm} \quad 62,1^{\circ} \mathrm{C}$. Amplifikasi membutuhkan DNA cetakan hasil isolasi sebanyak $10,5 \mu \mathrm{l}\left(\operatorname{tanpa} \mathrm{dH}_{2} 0\right)$. Kondisi untuk amplifikasi gen lipL32 adalah: predenaturasi awal selama 5 menit pada suhu $95^{\circ} \mathrm{C}$, denaturasi selama 30 detik pada suhu $95^{\circ} \mathrm{C}$, annealing selama 30 detik pada suhu $55^{\circ} \mathrm{C}$, elongasi selama 1 menit pada suhu $72{ }^{\circ} \mathrm{C}$. Amplifikasi dilakukan sebanyak 40 siklus dan diakhiri dengan ekstra elongasi selama 10 menit pada suhu $72{ }^{\circ} \mathrm{C}$. Elektroforesis dilakukan pada $100 \mathrm{~V}$ selama 45 menit atau sampai pewarna merah pelacakan bermigrasi lebih dari dua pertiga panjang baki gel. Gel diletakkan di bawah UV trans-illuminator dan hasilnya didokumentasikan untuk dianalisis.

\section{Hasil dan Pembahasan}

Pemeriksaan klinis sapi meliputi keadaan umum, pemeriksaan pulsus, nafas dan temperatur serta pemeriksaan sistem organ. Hasil pemeriksaan klinis disajikan pada Tabel 1.

Tabel 1. Hasil Pemeriksaan Klinis

\begin{tabular}{llll}
\hline No & Jenis Pemeriksaan & \multicolumn{1}{c}{ Hasil } & Keterangan \\
\hline 1 & BCS & $2,1 \pm 0,30$. & Normal \\
2 & Frekuensi nafas & $32 \pm 6,97 \mathrm{kali} /$ menit & Normal \\
3 & Puslus & $69 \pm 10,00 \mathrm{kali} /$ menit & Normal \\
4 & Suhu & $38,1 \pm 0,19^{\circ} \mathrm{C}$ & Normal \\
5 & Sistema organ & Tidak ada perubahan & Normal \\
\hline
\end{tabular}

Dari 12 sapi yang diperiksa, semuanya berada pada batas normal. Pemeriksaan terhadap semua sistem organ tidak ditemukan adanya perubahan. Infeksi Leptospira pada penelitian ini bersifat subklinis, diagnosis leptospirosis ditetapkan berdasarkan adanya antibodi dalam tubuh. Menurut Hamond et al., (2015) leptospirosis pada sapi sebagian besar bersifat asimtomatik sekalipun sapi menyebarkan leptospira bersama urin. Tidak adanya gejala klinis pada sapi-sapi yang terinfeksi Leptospira ini, diduga karena faktor usia dewasa dan jenis serovar yang menginfeksi. Kondisi ini menyebabkan tidak adanya perbedaan klinis antara sapi yang sehat dengan sapi yang menderita leptospirosis, akibatnya peran sapi sebagai sumber penularan leptospirosis tidak disadari.

MenurutVijayacharietal.,(2007), MATadalah Gold standart untuk mendiagnosis leptospirosis karena kemampuannya mendeteksi antibodi spesifik terhadap spesies Leptospira dalam sampel serum. MAT telah digunakan sebagai uji referensi, namun demikian metode ini menunjukkan sensitivitas yang relatif rendah (Limmathurotsakul et al., 2012). Menurut Toyokawa et al., (2011) MAT tidak mampu mendeteksi antibodi pada awal penyakit. Kelemahan ini telah menyebabkan peningkatan pengembangan dan penggunaan diagnostik berbasis asam nukleat, seperti konvensional dan real-time polymerase chain reaction (PCR) dan metode amplifikasi isotermal, yang menonjolkan sensitivitas tinggi (Ahmed et al., 2012). Metode PCR adalah metode yang secara 
langsung mendeteksi adanya Leptospira dalam sampel dan lebih banyak digunakan untuk deteksi Leptospira patogen karena memiliki sensitivitas tinggi dan kemampuan untuk mendiagnosis dini (Chirathaworn et al., 2007). Pemeriksaan dengan PCR merupakan metode alternatif untuk mendeteksi gen LipL32 leptospira menggunakan sampel urine (Satbige et al., 2020). LipL32 adalah protein yang paling menonjol dalam profil protein Leptospira, lipoprotein ini penting dalam patogenesis, diagnosis, dan pencegahan leptospirosis (Haake et al., 2010). Hasil PCR urin sapi disajikan pada Gambar 1.
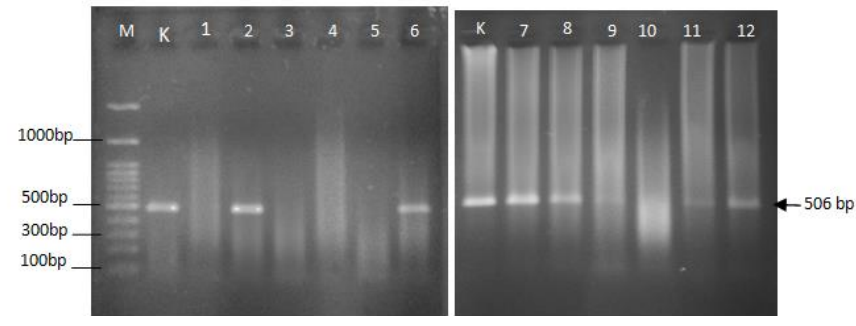

Gambar 1. Hasil elektroforesis gen LipL32 Leptospira dari sampel urin sapi.

$\mathrm{M}=$ marker, $\mathrm{K}=$ kontrol, $1-12$ = sampel.

Dari 12 sampel yang dilakukan PCR, 7 sampel (58\%) menunjukkan hasil positif dengan terbentuknya band pada 506 bp. Pada penelitian ini tidak semua sapi seropositif leptospirosis terdeteksi mengeluarkan leptospira bersama urine. Pada sapi yang baru saja mengalami infeksi (fase leptospiremia) akan memberikan hasil PCR urine negatif karena leptospira masih ada dalam darah dan tidak dijumpai dalam urine. Menurut Gonzales et al., (2013) metode ini mampu mendeteksi 100 leptospira / mL plasma, serum, darah utuh, atau urine, dan 0,7 setara genom (GE) / reaksi jaringan parafin. Harkin et al., (2003) menjelaskan fase leptospiremia dan leptospiruria dan kemampuan PCR untuk mendeteksi leptospira seperti Gambar 2 .

Menurut Mulyani et al., (2016) serovar penyebab leptospirosis pada sapi di daerah aliran sungai Progo didominasi serovar Hardjo $(38,0 \%)$, serovar Ichterohaemorrhagie $(15,0 \%)$, dan serovar Bataviae (9,0\%). Ramadhani dan Yunianto (2012) melaporkan kasus Leptospirosis pada manusia di Kulon Progo tahun 2011 disebabkan oleh Leptospira serovar Harjo, Semaranga, Ichterohaemorrhagie, Bataviae, dan Patoc. Adanya

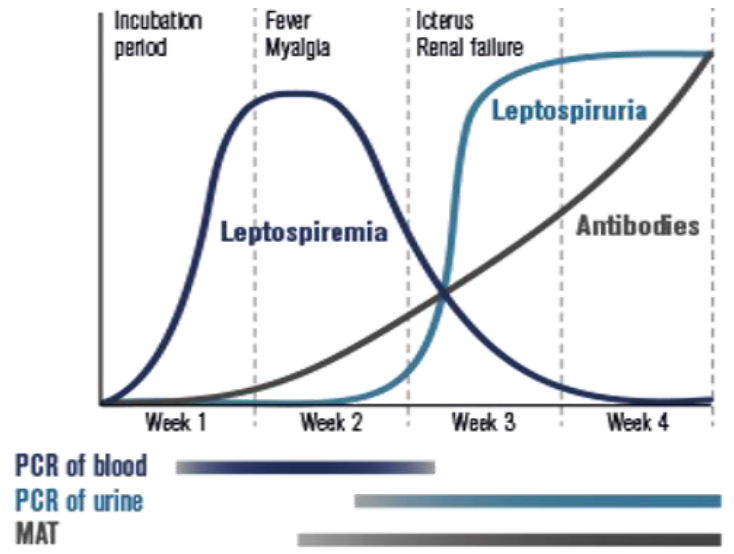

Gambar 2. Fase leptospiremia dan leptospiruria (Harkin et al., 2003).

kesamaan beberapa serovar yang ada pada sapi dan manusia menguatkan dugaan bahwa di Kulon Progo sapi juga memiliki peran sebagai sumber penularan leptospirosis. Hewan pembawa merupakan risiko zoonosis potensial. Manusia terinfeksi melalui urin pembawa secara langsung atau tidak langsung oleh air atau tanah yang terkontaminasi (Adler dan Moctezuma, 2010).

\section{Kesimpulan}

Berdasarkan hasil penelitian ini dapat disimpulkan bahwa sapi yang seropositif leptospirosis di Kulon Progo tidak menunjukkan gejala klinis leptospirosis. Leptospira interrogans dalam urin ditemukan pada 7 (58\%) sapi seropositif leptospirosis. Deteksi leptospirosis dengan komponen membran Lip32 menggunakan PCR sangat menguntungkan untuk mendeteksi leptospirosis subklinis. Keberadaan leptospira dalam urin sapi dapat berperan sebagai sumber penularan bagi hewan lain, manusia maupun lingkungan.

\section{Daftar Pustaka}

Adler B, de la Pena Moctezuma A. 2010. Leptospira and leptospirosis. Vet Microbiol., 140(3-4):287-296.

Ahmed, S.A., Sandai, D.A., Musa, S., Hoe, C.H., Riadzi, M., Lau, K.L. \& Tang, T.H. 2012. Rapid Diagnosis of Leptospirosis by Multiplex PCR. Malaysian Journal of Medical Sciences 19: 9-16 
Besung, I.N.K. 2012. Leptospirosis Pada Hewan. Proceedings of 8th National Conggres of Indonesia Association of Clinical Microbiology (PAMKI), November1st November 3th 2012, Bali, Indonesia

Brown, P.D., Mckenizie, M., Pinnock, M., McGrowder, D. 2011. Environmental risk factors associated with leptospirosis among butcher and their associates in Jamaica. IJOEM, 20(1):47-57.

Chirataworn, C., Kaewopas, Y., Poorawan, Y., and Suwancharoen, D. 2007. Comparation of A Slide Agglutination Test, Leptotek Dri-dot, and IgM-Elisa with Microscopic Agglutination Test for Leptospirosis Antibody Detection. Research Note, 38 (6), 111-114.

González S, Geymonat JP, Hernández E, Marqués JM, Schelotto F, Varela G. 2013. Usefulness of real-time PCR assay targeting lipL32 gene for diagnosis of human leptospirosis in Uruguay. J Infect Dev Ctries. 7:941-945.

Haake, D.A., and Matsunaga, J. 2010. Leptospira: A Spirochaeta with a hybrid outer membrane. Mol. Microbiol., 7714, 805-814.

Hamond, C., Martin, G., Lilenbaum, W., Pinna, M., and Medeiros, M.A. 2015. Infection by Leptospira spp. In Cattle in Tropical Region, Rio de Janeiro, Brazil. Am. J. Trop. Med. Hyg. 92(1):210.

Harkin, K.R., Roshto, Y.M., Sullivan, J.T., Purvis, T.J., and Chengappa, M.M. 2003. Comparison of polymerase chain reaction assay, bacteriologic culture, and serologic testing in assessment of prevalence of urinary shedding of leptospires in dogs. $J$ Am Vet. Med Assoc 222(9): 1230-1233.

Limmathurotsakul, D., Turner, E.L., Wuthiekanun, V., Thaipadungpanit, J., Suputtamongkol, Y., Chierakul, W. 2012. Fool's gold: why imperfect reference tests are undermining the evaluation of novel diagnostics: a reevaluation of 5 diagnostic tests for leptospirosis. Clin Infect Dis, 55:322-31.
Mulyani, G.T., Sumiarto, B., Artama, W.T., Hartati, S., Juwari, Sugiwinarsih, S., Putra, H.R.C., Widodo, E. 2016. Kajian Leptospirosis pada Sapi Potong di Daerah Aliran Sungai Progo, Daerah Istimewa Yogyakarta. Jurnal Kedokteran Hewan 10(1):68-71.

Musso, D., La Scola, B. 2013. Laboratory diagnosis of leptospirosis: a challenge. $J$ Microbiol Immunol Infect;46(4):245-52.

Ramadhani, T., Yunianto, B. 2012. Reservoir dan Kasus Leptospirosis di Wilayah Kejadian Luar Biasa. J. Kes. Masy. Nas. 6(4), 162168.

Satbige, A.S., Patil, N.A., Awati, B., and Sandeep, H. 2020. Detection of leptospirosis in the urine of cattle in North Karnataka, South India. Journal of Enthomology and Zoology Studies 8(1):727-729.

Thaipadungpanit, S.B.J., Amornchai, P., Wuthiekanun, V., Limmathurotsakul, W.C.D., Day, N.P., Peacock, S.J. 2011. Molecular detection and speciation of pathogenic Leptospira spp. in blood from patients with culture-negative leptospirosis. BMC Infectious Diseases.; 11 (2):338.

Toyokawa, T., Ohnishi, M., Koizumi, N. 2011. Diagnosis of acute leptospirosis. Expert Rev Anti Infect Ther.;9(1):111-21

Vijayachari, P. 2007. Leptospira in Leptospirosis Laboratory Manual. World Health Organization, Country office for India. 8-12. 